\title{
The Libertarian roots of the EFF.
}

\author{
Camille Akmut
}

\begin{abstract}
A full review of EFF staffers between the years 2001 and 2004, and their employment history, reveals conflicts of interests with big technology companies (that have a history of privacy violations). Paired with an analysis of the political/philosophical positions of key members, including founders and presidents, this study highlights wider problems affecting the computer science and technology world in general. Perhaps, the EFF cannot commit to an all-encompassing defense of privacy - equally harsh to governments and companies - because it does not know its own history.
\end{abstract}


"old people wouldnt be fucking helpless if you werent sending them fucking checks to sit on their ass and lay in hospitals all day." (Edward Snowden, President of the EFF-affiliated FPF.)

"We're still figuring that out" (EFF's Donna Wentworth, about Google, before joining Google.)

"Well, virtually no one in the Internet industry is (...) "safe"" (EFF's Fred von Lohmann, about Google, before joining Google.)

"Strange; odd.

she had a queer feeling that they were being watched" (Oxford Dictionary definition "queer") 


\section{Introduction}

It would seem enough to mention that the founder of the EFF, John Perry Barlow, was a self-identified "cyberlibertarian", while the President of the EFF-affiliated Freedom of the Press Foundation, Edward Snowden, whom Barlow considered a "good friend", and likewise, was and perhaps still is what can only be accurately described as an extreme, or hardcore, Libertarian, whose visions of society border on capitalism Darwinism, a staunch supporter of the polician Ron Paul of the Libertarian Party of the USA.

This would have many consequences : we know that this ideology has as main tenet or doctrine a distrust of government and governments and favors as little a version of them as possible. But, how would such an ideological soil permit a full defense of privacy, both and equally concerned with spying from governments and corporations alike? But, we approach this question differently here.

We review staff of the EFF employed between December 2001 and about 2005, leading up to the protest letter against Google and its product Gmail it did not sign. We highlight double employments that raise questions as to the independence of the EFF from private sector interests, and its ability to fulfill its mission fully.

\section{Infrastructure : EFF employees (2001- 2004)}

\begin{tabular}{cccc}
\hline Employee & Position & First appears & Google and co. \\
Fred von Lohmann & Senior Staff Attorney & 2001 & Yes (employee) \\
Donna L. Hoffman & Policy Fellow & 2001 & Yes (grant) \\
Donna Wentworth & Writer/Activist & $2005(?)$ & Yes (employee) \\
\hline
\end{tabular}

Perhaps, the EFF cannot be as harsh to big technology companies as it would like to be, and it wish it were, in the fantasies that its staffers have of itself, and simultaneously also themselves, because - and for the simple but real reason of countless consequences - that some of its employees, while superficially committed to privacy, also keep a look out for lucrative career progressions at the very same companies they should - if not critize - at least analyze. Their heart is one place, but their mind constantly in many other distant corners.

"We're still figuring that out" wrote EFF's Donna Wentworth in response to the launch of Gmail by Google in 2004, in the name of the EFF. Meanwhile 31 privacy organizations including major peers such as EPIC or Privacy International were busy organizing letters and protests.

But, perhaps this was so, because the most adroit - lukewarm, neither too cold or warm - Donna Wentworth was figuring things out for herself instead : she joined Google soon afterwards. Donna Wentworth, everyone knows, is not bright : she will never go on to write books like Capital or Distinction: A Social Critique of the Judgment of Taste, but what she lacks in smarts she makes up thousandfold with her street-smart, network- 
savvy, business-first ways. Sweet like sacharrine, and false. Saint Donna has a philosophy of her own : her own.

But, we now leave the objective structures that are those of the infrastructure, and turn to what Marx called the superstructure, where ideas reside - that are a reflection, mirror of them.

\section{Superstructure : EFF's Libertarian philo- sophical roots}

In messages, that are so brutal and undiluted, that they go beyond even the most extreme and hardcore versions of Libertarianism, they can only be accurately described as some primal form of economic Darwinism, nothing less than an "Ausrottung" (termination) of the poor and weak in our societies, Edward Snowden wrote :

Edward Snowden save money? cut this social security bullshit

User 11 hahahayes

User 18 Yeah! Fuck old people!

User 11 social security is bullshit

User 11 lets just toss old people out in the street

User 18 Old people could move in with [User11].

User 11 NOOO

User 11 they smell funny

Edward Snowden Somehow, our society managed to make it hundreds of years without social security just fine

Edward Snowden you fucking retards

Edward Snowden Magically the world changed after the new deal, and old people became made of glass.

(...)

Edward Snowden [they/old people] wouldnt be fucking helpless if you werent sending them fucking checks to sit on their ass and lay in hospitals all day.

The same Edward Snowden who is now President of the EFF-affiliated Freedom of the Press Foundation, and appeared regularly in talk shows with the founder of the EFF, John Barlow, when he did not prefer being interviewed by the Libertarian Party politician Ron Paul.

Our heroes are human. They do grand acts and pay back their debt. We love them, but they sometimes make it so hard for us to love them back. But, it is not the fact that we do errors that matters - this only makes us human - but how we deal with, and confront them. 


\section{Conclusion : "[EFF]: What's the Deal?"}

"We're still figuring that out" wrote EFF's Donna Wentworth about Google, its products in 2004 (before joining them).

Has the EFF finally figured it out yet?

In this libertarian ideology, in which it soaks, competition amongst enterprises is traditionally presented as vital and counter-argument to "big gov" : perhaps it is time then the EFF got competition.

We do not want and do not need a watered-down defense of privacy conceived as mere, minimal "no spying by governments" in these times that are ours, and whose disruptions on all of our lives are so great, and can only be expected to become ever, and ever greater in the future.

When Defense politicians join armament companies, we rightfully exercise critic. When former environment activists turn global warming doubters, we answer back. When white academics are endowed with the task of studying the slavery heritage of Cambridge, "brave academics" publish in The Guardian. But, when these same happenings occur within academic computer science or in technology - as they now so often do - we turn a blind eye and resign ourselves to a polite, uneasy reckoning and understanding that "everyone is a master of their own lives". But, to Libertarian counter-arguments, we respond with hard counterpunches.

The EFF staffers go down on their knees, bend down and pull down their suit trousers and skirts and nylon stockings? We take them in our arms, pull them back up, we bend them back straight, and kiss them, because we love them.

A queer, uneasy feeling? We shout, and express it. (We never feel more at home than when we encounter "Rob gay yuppies" or "Are you proud of what you have become?" graffiti on walls.)

They hold back punches, and look sideways? By God, we will blow your wigs and designer high heels off and counterpunch your so hard that, in your daze, you will find a way back.

"It really concerns me how little this sort of corporate behavior bothers those outside of technology circles. Society really seems to have developed an unquestioning obedience towards spooky types." wrote Edward Snowden further. He knows where to start now, as does Cindy Cohn. 


\section{Bibliography}

https://www .privacyrights .org/blog/thirty-one-privacy-and-civil-liberties-organizations-urge-goc Description : where the EFF wasn't, when it came down to it.

www .google.com

Description : the EFF's homepage, and favorite bookmark.

https://careers.google.com/

Description : at least a thousand hits a day by EFF staffers who can't wait to leverage their privacy, nonprofit credentials into a lucrative private sector career.

https://www . accessnow .org/profile/donna-wentworth/

Description : the most adroit Donna Wentworth, who dances on all feet and to all songs, always lands back on greener sides of the hill, looks in all directions, and goes wherever the wind blows. Her degree in "critical theory" did not give her a right mind, and meant she was able to separate theory from practice, and education from real action.

https://battellemedia.com/archives/2006/10/a_brief_interview_with_ effs_fred_von_lohmann_on_youtube_copyright_google_and_more

Description : Fred von Lohmann is interviewed about Google, Youtube and co.. In the end, he preferred joining them, he understood them so well, he had stopped understanding himself.

https://business.gwu.edu/sites/g/files/zaxdzs1611/f/Hoffman-Donna_ FP_Curriculum-Vitae_2017.11.pdf

Description : Google cut her a $50.000 \$$ check so she could do her third-tier marketing "research" on among others "[gaining] consumer trust"... Had she only passed the fruit of her research to the EFF (in time).

https://www .eff .org/nl/deeplinks/2004/04/gmail-whats-deal

Description : EFF: What's the Deal?

https://arstechnica.com/tech-policy/2013/06/nsa-leaker-ed-snowdens-life-on-ars-technica/ Description : the real not-so gentle Snowden.

https://arstechnica.com/tech-policy/2013/06/exclusive-in-2009-ed-snowden-said-leakers-should-be 2/

Description : a hero we cannot bring ourselves to love with all of our heart.

https://epic.org/

Description : they don't take money from corporations, and perhaps deserve yours, "we haven't figured it out yet". 